\title{
FREQUENCY OF CYTOMEGALOVIRUS, RUBELLA, AND HERPES SIMPLEX VIRUS IN EMBRYONIC TISSUES OF WOMEN WITH MISSED ABORTION
}

\section{AVESTA SEERWAN AHMAD ${ }^{1}$, YASIN KAREEM ${ }^{2}$}

\section{Abstract:}

Background and objectives: Spontaneous abortion (SA), also known as miscarriage, is considered as one of the most frequent problems a woman may face during early pregnancy, is not only related to morbidity or mortality, but also has an obvious social and psychological impact on women. An abortion is the removal or expulsion of an embryo or fetus from the uterus, resulting in lor caused by its death, the loss of a pregnancy occurs within the first 2024 weeks of gestation, after which, fetal death is known as a stillbirth. This study was first aimed to assess the frequency of, Cytomegalovirus, Rubella and Herpes simplex virus in embryonic tissues of women with abortion. Next to find out the sociodemographic characteristics of the studied populations.

Methods: This cross-sectional prospective study was carried out from February 2019 through January 2020.This study prospectively deal with tissues from conceptus after abortion which collected from maternity teaching hospital in Erbil city, Iraq for the diagnosis of frequency of CMV, rubella and herpes simplex virus. RT-PCR were used in tissue analysis. SPSS version 25 was used for data entry and analysis.

Results: Out of 72 cases with spontaneous abortion $8(11.1 \%)$ were due to human Cytomegalovirus, $2(2.8 \%)$ were due to Rubella virus and 1case $(1.4 \%)$ was due to Herpes simplex virus, the age range of participants was $17-45$ years with mean \pm Sd of $(31.29 \pm 6.11)$ years. The highest percentages of participants were in their second and third decades of life (40.5\% and $37.5 \%$ respectively) and about $86.1 \%$ of them were un-employed (housewives) and majority about $57 \%$ of them attending primary school, and more than half percentage (63.8\%) of them have intermediate economic state. Histopathological analysis shows that out of 72 cases only 9 samples $(16.6 \%)$ show histopathological abnormalities. A statistically significant association was found between Rubella infection and histopathological abnormality.

Conclusions: Cytomegalovirus infection was more prevalent among the study samples, followed by Rubella infection then Herpes simplex virus infection by real-time polymerase chain reaction, on other hand $16.6 \%$ of samples shown nonspecific histopathological abnormality.

Keywords: Spontaneous abortion, real-time polymerase chain reaction, Human cytomegalovirus, Rubella, Human Herpes simplex virus.

\footnotetext{
${ }^{1}$ M.B.Ch. B, H.D. in F.M
}

${ }^{2}$ M.B.Ch. B, M. Sc, Ph. D 


\section{INTRODUCTION:}

Spontaneous abortion (SA), also known as miscarriage, is considered as one of the most frequent problems a woman may face during early pregnancy, is not only related to morbidity or mortality, but also has an obvious social and psychological impact on women. It was estimated that $6-15 \%$ of all clinically detected pregnancies end with spontaneous abortion, there are many more pregnancies that end with abortion prior to being clinically recognized. It is estimated that about $30 \%$ of all conceptions result in a live birth (Rouse et al., 2017).

Early miscarriage is defined as pregnancy loss during the first trimester of pregnancy (less than 12 weeks of gestation) and occurs in up to one in five pregnancies. Late miscarriage occurs during the second trimester (12-24 weeks of gestation) and is less common, occurring in 1-2\% of pregnancies (Giakoumelou et al., 2016). As many as $50 \%$ of all pregnancies end in miscarriage, mostly before the woman realized that she is pregnant and about $15-25 \%$ of recognized pregnancies will end in an abortion. Early pregnancy loss, which occurs in the first trimester, is the most common type, occurring in $10 \%$ of all clinically recognized pregnancies, approximately $80 \%$ of all cases of pregnancy loss occur within the first trimester. In the first trimester, the terms miscarriage, spontaneous abortion, and early pregnancy loss are used interchangeably (Ford and Schust, 2009).

Approximately $50 \%$ of all cases of early pregnancy loss are due to fetal chromosomal abnormalities. The most common risk factors identified among women who have experienced early pregnancy loss are advanced age of both parents (Larsen et al., 2013).

Infections during pregnancy can cause significant effects on the fetus. For example, cytomegalovirus (CMV), rubella virus and herpes simplex virus are well-known causes of congenital malformations with high morbidity and mortality to unborn child through their early life (Alvarado-Esquivel et al., 2018).

Congenital cytomegalovirus infection is a major cause of central nervous system and sensory impairments that affect cognition, motor function, hearing, language development, vestibular function, and vision, Congenital CMV infection is common, 
occurring in approximately $0.5 \%$ to $1 \%$ of live births (Zalei et al., 2017).

Rubella infection in pregnant women, especially during the first trimester, can result in miscarriages, stillbirths, and congenital rubella syndrome (CRS), in Congenital Rubella Syndrome (CRS), rubella virus is able to infect the placenta, spread to the fetus, and alter the function of multiple fetal systems by interfering with organ formation and causing systemic inflammation. congenital rubella syndrome (CRS) include a cluster of birth defects that often includes cataracts, hearing loss, mental retardation, and congenital heart defects, there is no specific treatment for rubella and CRS, but they can be prevented by immunization (Lulandala et al., 2017).

Herpes simplex viruses' types 1 and 2 (HSV-1 and HSV-2) are among the most common human infectious viral pathogens, herpes affects some 30$60 \%$ of women receiving obstetric care, with newborns particularly susceptible to neonatal infection and severe herpetic disease, transmission risk to the baby can be as high as $50 \%$ during parturition from mothers with newly acquired genital HSV infections (LeGoff et al., 2014). . Over half of neonatal HSV infections result in disseminated disease or encephalitis, with long-term neurologic morbidity in $2 / 3$ of those who survive encephalitis, either serotype of HSV may cause disease in newborns (HSV-1 or HSV2), but emerging data suggests a rising incidence of HSV-1 genital infection, and a parallel predominance of HSV-1 as a cause of newborn disease (Shi et al., 2018). The main objectives of the study is to find out frequency of, Cytomegalovirus, Rubella and Herpes simplex virus in embryonic tissues of women with abortion and to estimate the sociodemographic characteristics of the studied populations.

\section{METHODS:}

\section{Design of the study:}

A cross sectional prospective study in which tissues from conceptus after abortion are collected from maternity teaching hospital in Erbil city, Iraq.

\section{Setting and time:}

This study carried out in emergency unit of Maternity teaching hospital in Erbil city, during period February 2019 to January 2020 include data collections, analysis, writing and finalizing the report. Maternity teaching hospital was established in 
1982, in Erbil city, it contains different departments for service of patients.

\section{Study population:}

Data collection done by using a semistructured questionnaire designed for the study. A total, 75cases were included in the study. All sociodemographic and antenatal characteristics such as age, education level, economic level, occupation, residence, gestational age, history of abortion and gravity were recorded.

\section{Inclusion criteria:}

All cases of spontaneous abortions who attended emergency unit of Maternity teaching hospital in Erbil city, are included in the study.

\section{Exclusion criteria:}

1. Improper tissue collection is excluded from the study.

2. Moller pregnancy.

3. Induced abortion.

\section{Data collection:}

Data collection based on product of conception which collected after abortion in convenient containers which contain $20 \mathrm{cc}$ of $10 \%$ buffered formaldehyde for preservation of the samples (Fixation), each tissue sample was placed in different container and labeled with proper information's of the patients and give a convenient code.

Then the tissues are transported to specialized laboratory to processed it for further examination and forming FFPE or Formalin-Fixed ParaffinEmbedded which is a method of preservation of cell tissues used extensively in profiling gene expression. FFPE Samples can be stored at room temperature and therefore avoid the complexities and risks of freezing, in which the tissue is converted into tissue blocks by different steps, includes:

\section{Grossing:}

also called as "cut-up", which involve a careful examination of the specimen and dissecting it to a representative piece.

\section{Processing:}

by using an automated instrument called "tissue processors" which allow the specimens to be infiltrated with a sequence of different solvents finishing in molten paraffin wax), the duration of processing last for twelve hours. Tissue processing done by dehydration in graded alcohol $70 \%$ for 2 hours, 
$80 \%$ for 2 hours, $95 \%$ for 2 hours, $95 \%$ for 2 hours, $100 \%$ for 2 hours, another $100 \%$ for 2 hours, then clearing by 3 xylines each for 1 hour, impregnation in paraffin for at least 4 hours at 60c".then 3 micron thick sections done by microtome, fixed and dewaxing done in oven for 3 hours then staining with routine $\mathrm{H} \& \mathrm{E}$ staining which include:

Slides put in 2 xylines each for 5 minutes, Tape water for 5 minutes, Stained with Hematoxyline for 2-5 minutes, running water for 1 minute, $70 \%$ ethanol for 5 minutes, Stained with Eosin for 0.5-minute, $70 \%$ ethanol for 5 minutes, $80 \%$ ethanol for 5 minutes, $90 \%$ ethanol for 5 minutes, $100 \%$ ethanol for 5 minutes, Dry in oven for 1 minute, Xyline before mounting, Mounted with DPX and cover slipped, Slides examined by microscope.

\section{Embedding:}

In which the specimens are placed in an embedding center and placed in wax-filled molds, the specimen "block" is now allowed to solidify on a cold surface and the cassette now filled with wax and forming the block.

\section{Sectioning:}

Sections are cut on a precision instrument called a "microtome" using extremely fine steel blades. Paraffin sections are usually cut at a thickness of $3-5 \mu \mathrm{m}$ ensuring that only a single layer of cells makes up the section, sections then "floated out" on the surface of warm water in a flotation bath to flatten them and then picked up onto microscope slides.

\section{Staining:}

The routine stain used universally is the hematoxylin and eosin (H\&E) stain, with this method cell nuclei are stained blue and cytoplasm and many extra-cellular components in shades of pink, after staining, the sections are covered with a glass coverslip and usually $\mathrm{H} \& \mathrm{E}$ done manually in the following steps:

Slides were put in tape water for 1 minute, stained with hematoxylin for 2 minutes, rinsed with tape water for 1 minute, $70 \%$ ethanol for 2 minutes, $80 \%$ ethanol for 2 minutes, $90 \%$ ethanol for 2 minutes, $100 \%$ ethanol for 5 minutes, slides put in xylene for 1 minute (3 times each 2 minutes), mounting with DPX \& cover slipped and are then sent to a pathologist. 
There after the tissue blocks are examined at Zanko Genetic Unit, in Zanko private hospital, Erbil city, Iraq, by specialist, the tissue blocks initially cut and dewax in water bath for 2 hours, tissue section is prepared for tissue extraction. Tissue extraction don by special kit RealLine Extraction 100 kit. The protocol involves:

Prepare and label an appropriate number of $2 \mathrm{ml}$ tubes for specimens, add $30 \mu \mathrm{l}$ of IC (internal control) solution to each tube, add $100 \mu \mathrm{l}$ of each patient specimen to the appropriately labelled tube, add $300 \mu \mathrm{l}$ of Lysis Reagent with Sorbent to each tube. Vortex for 10-15 seconds, place the tubes into Thermal Shaker, and incubate for 10 minutes at $65^{\circ} \mathrm{C}$ and $1300 \mathrm{rpm}$, add $400 \mu \mathrm{l}$ of Solution for NA precipitation to each tube, then vortex the tubes for 10-15 sec. Let stand for 3-5 min at $(18-25){ }^{\circ} \mathrm{C}$. Centrifuge at $13000 \mathrm{rpm}$ for $5 \mathrm{~min}$ at $(18-25){ }^{\circ} \mathrm{C}$. carefully place the tubes into Magnetic Rack, then carefully remove the supernatant without disturbing the pellet, add $500 \mu$ of Wash solution № 1 to each tube, vortex for 10-15 sec. Centrifuge at $13000 \mathrm{rpm} 5 \mathrm{~min}$, without stirring the pellet, carefully place the tubes into Magnetic Rack, carefully remove the supernatant without disturbing the pellet, add $300 \mu \mathrm{l}$ of wash solution № 2 to each tube. Vortex for 10-15 sec. Centrifuge at $13000 \mathrm{rpm}$ for $5 \mathrm{~min}$, carefully place the tubes into Magnetic Rack, carefully remove the supernatant without disturbing the pellet, dry the pellet in open tubes for 2-3 min at (18 25) ${ }^{\circ} \mathrm{C}$, adding $200 \mu \mathrm{l}$ of Specimen Diluent to the tube if the number of assays performed with this probe will account to 1-3. Add $600 \mu \mathrm{l}$ of Specimen Diluent to the tube if the number of assays is higher. Vortex thoroughly to re-suspend the pellet. Place the tubes into thermal shaker, and incubate for $10 \mathrm{~min}$ at $56{ }^{\circ} \mathrm{C}$ and $1300 \mathrm{rpm}$. Centrifuge for $1 \mathrm{~min}$ at $13000 \mathrm{rpm}$. Samples are ready for PCR or RT-PCR.

\section{Polymerase chain reaction protocol for CMV involve:}

By prepare an appropriate number of $0.2 \mathrm{ml}$ tubes and plate for PCR. Label each tube for each specimen and control, add $25 \mu \mathrm{l}$ of prepared Master Mix to each $0.2 \mathrm{ml}$ tube, add $25 \mu$ of corresponding isolated DNA solution to each tube using a separate pipette tip with filter, place the tubes into the Real Time PCR system. 
Program Real Time PCR system: For Eco $^{\text {TM }}$ Real-Time PCR System:

Stage $1: 50^{\circ} \mathrm{C}$ for $2 \mathrm{~min}$

Stage $2: 95^{\circ} \mathrm{C}$ for $2 \mathrm{~min}$

Stage $3: 94^{\circ} \mathrm{C}$ for 10 sec 50 cycles

$$
60^{\circ} \mathrm{C} \text { for } 40 \mathrm{sec}
$$

Measure the fluorescence at $60^{\circ} \mathrm{C}$

After selecting the amplification detection channels, collect data through FAM channel and collect data through ROX channel for the detection of amplification signal of CMV DNA, program the positions of test tubes with samples, positive and negative controls according to the instruction manual for the Real Time PCR system in use and run the program.

\section{Analysis of results:}

The program should detect in Positive Control sample, increase of the Cytomegalovirus DNA amplification signal along channel ROX (Orange) and determine the $\mathrm{Ct}$ value.

The sample is considered positive, i.e. contains Cytomegalovirus DNA, when $\mathrm{Ct}$ value via ROX (Orange) channel for this sample is less than or equals to 40.

\section{Polymerase chain reaction protocol for Rubella involve:}

Prepare an appropriate number of 0.2 $\mathrm{ml}$ tubes, label each tube for each specimen and control sample, add 25 $\mu 1$ of prepared MM (Master Mix) to all test tubes, add $25 \mu \mathrm{l}$ of corresponding extracted RNA solution to each tube using a separate pipette tip with filter, add $25 \mu \mathrm{l}$ of $\mathrm{NC}$ and $\mathrm{PC}$ to the corresponding tubes. Tightly close the tubes with caps.

place the tubes into the Real Time PCR system. Program Real Time PCR system as follows: For $\mathrm{Eco}^{\mathrm{TM}}$ RealTime PCR System:

Step 1: $45^{\circ} \mathrm{C} 30 \mathrm{~min}$

Step 2: $94{ }^{\circ} \mathrm{C} 1 \mathrm{~min}$

Step 3: $94{ }^{\circ} \mathrm{C} 10 \mathrm{sec}$

cycles

$$
60{ }^{\circ} \mathrm{C}^{*} 40 \mathrm{sec}
$$

* Measure the fluorescence at $60^{\circ} \mathrm{C}$.

Select the amplification detection channels: collect data through the FAM channel and collect data through ROX channel for the detection of amplification signal of Rubella gene, program the positions of tubes with specimens, $\mathrm{PC}$ and $\mathrm{NC}$ according to the Instruction Manual for the cycler in use, run the program.

\section{Rubella Data Analysis and Interpretation:}

The specimen is considered positive, i.e. containing Rubella gene, if $\mathrm{Ct}$ 
value through ROX channel for this

specimen is less than or equals to 40 ,

\section{Polymerase chain reaction protocol}

\section{for HSV 1\&2 involve:}

Prepare an appropriate number of 0.2 $\mathrm{ml}$ tubes label each tube for each specimen and control, add $25 \mu \mathrm{l}$ of prepared Master Mix to each $0.2 \mathrm{ml}$ tube, add $25 \mu \mathrm{l}$ of corresponding isolated DNA solution to each tube using a separate pipette tip with filter. close the tubes, place the tubes into the real-time PCR system, program real time PCR system, for Eco ${ }^{\mathrm{TM}}$ RealTime PCR System:

Step 1: $50^{\circ} \mathrm{C} 2 \mathrm{~min}$

Step 2: $95^{\circ} \mathrm{C} 2 \mathrm{~min}$

Step 3: $94^{\circ} \mathrm{C} 10 \mathrm{sec} \quad 50$ cycles

\section{RESULT}

Total of 72 women included in the study, the age range of participants was 17-45 years with mean $\pm \mathrm{Sd}$ of $(31.29$ \pm 6.11 ) years. The highest percentages of participants were in their second and third decades of life $(40.5 \%$ and $37.5 \%$

$$
60^{\circ} \mathrm{C}^{*} 40 \mathrm{sec}
$$

* Measure the fluorescence at $60^{\circ} \mathrm{C}$.

There after select the amplification detection channels, collecting data through ROX channel for the detection of amplification signal of HSV-2 DNA, Collecting data through HEX channel for the detection of amplification signal of HSV-1 DNA. Then run the program.

\section{Data Analysis and Interpretation:}

The sample is considered positive (containing HSV-1 DNA) when $\mathrm{Ct}$ value via HEX channel for this sample is less than or equals to 40 and also the sample is considered positive (containing HSV-2 DNA) when $\mathrm{Ct}$ value via ROX channel for this sample is less than or equals to 40 ,

respectively) and about $86.1 \%$ of them were un-employed (housewives) and majority about $57 \%$ of them attending primary school, and more than half percentage $(63.8 \%)$ of them have intermediate economic state. The detail of sociodemographic characteristics is shown in Table 1. 
Table 1: Socio-demographic characteristics of the study sample.

\begin{tabular}{|c|c|c|}
\hline Variables & No & $(\%)$ \\
\hline $\begin{array}{c}\text { Age } \\
\text { 17- 30 years } \\
\text { 31-40 years } \\
\text { 41-50 years }\end{array}$ & $\begin{array}{l}29 \\
27 \\
16\end{array}$ & $\begin{array}{l}(40.5) \\
(37.5) \\
(22.0)\end{array}$ \\
\hline Total & 72 & (100.0) \\
\hline $\begin{array}{c}\text { Occupation } \\
\text { Unemployed } \\
\text { Employed }\end{array}$ & $\begin{array}{l}62 \\
10\end{array}$ & $\begin{array}{l}(86.1) \\
(13.9)\end{array}$ \\
\hline Total & 72 & (100.0) \\
\hline $\begin{array}{l}\text { Educational level } \\
\text { Primary } \\
\text { Secondary } \\
\text { Higher education } \\
\text { Illiterate } \\
\text { Total }\end{array}$ & $\begin{array}{c}41 \\
13 \\
7 \\
11 \\
72\end{array}$ & $\begin{array}{c}(57.0) \\
(18.0) \\
(9.7) \\
(15.3) \\
(100.0)\end{array}$ \\
\hline $\begin{array}{c}\text { Economic } \\
\text { Low } \\
\text { Intermediate } \\
\text { high }\end{array}$ & $\begin{array}{c}21 \\
46 \\
5\end{array}$ & $\begin{array}{c}(29.2) \\
(63.8) \\
(7.0)\end{array}$ \\
\hline Total & 72 & (100.0) \\
\hline $\begin{array}{c}\text { Residency } \\
\text { Urban } \\
\text { rural }\end{array}$ & $\begin{array}{l}52 \\
20\end{array}$ & $\begin{array}{l}(72.2) \\
(27.8)\end{array}$ \\
\hline Total & 72 & (100.0) \\
\hline
\end{tabular}

The study showed that most of abortion cases were in first trimester of about 64 cases $(88.9 \%)$ High percentage about $(52.7 \%)$ of cases have abortion for the second time, and among them 40 cases $(55.6 \%)$ were multiparous, as shown in Table 2. 
Table 2: Antenatal characteristics of the study population.

\begin{tabular}{ccc}
\hline Variables & No & $(\%)$ \\
\hline Trimester & 64 & $(88.9)$ \\
First & 8 & $(11.1)$ \\
Second & 0 & $(0.0)$ \\
Third & 72 & $(100.0)$ \\
Total & & \\
Abortion numbers & 11 & $(15.4)$ \\
First & 38 & $(52.7)$ \\
Second & 18 & $(25.5)$ \\
Third & 5 & $(6.9)$ \\
More & 72 & $(100.0)$ \\
Total & & \\
Parity & 25 & $(34.8)$ \\
Primipara & 40 & $(55.6)$ \\
Multipara & 7 & \\
Grand Multipara & & $(100.0)$ \\
Total & 72 &
\end{tabular}

Histopathological analysis shows that out of 72 cases only 9 samples $(16.6 \%)$ show histopathological abnormalities and 63 samples $(83.4 \%)$ show no abnormalities, as showed in Fig.1.

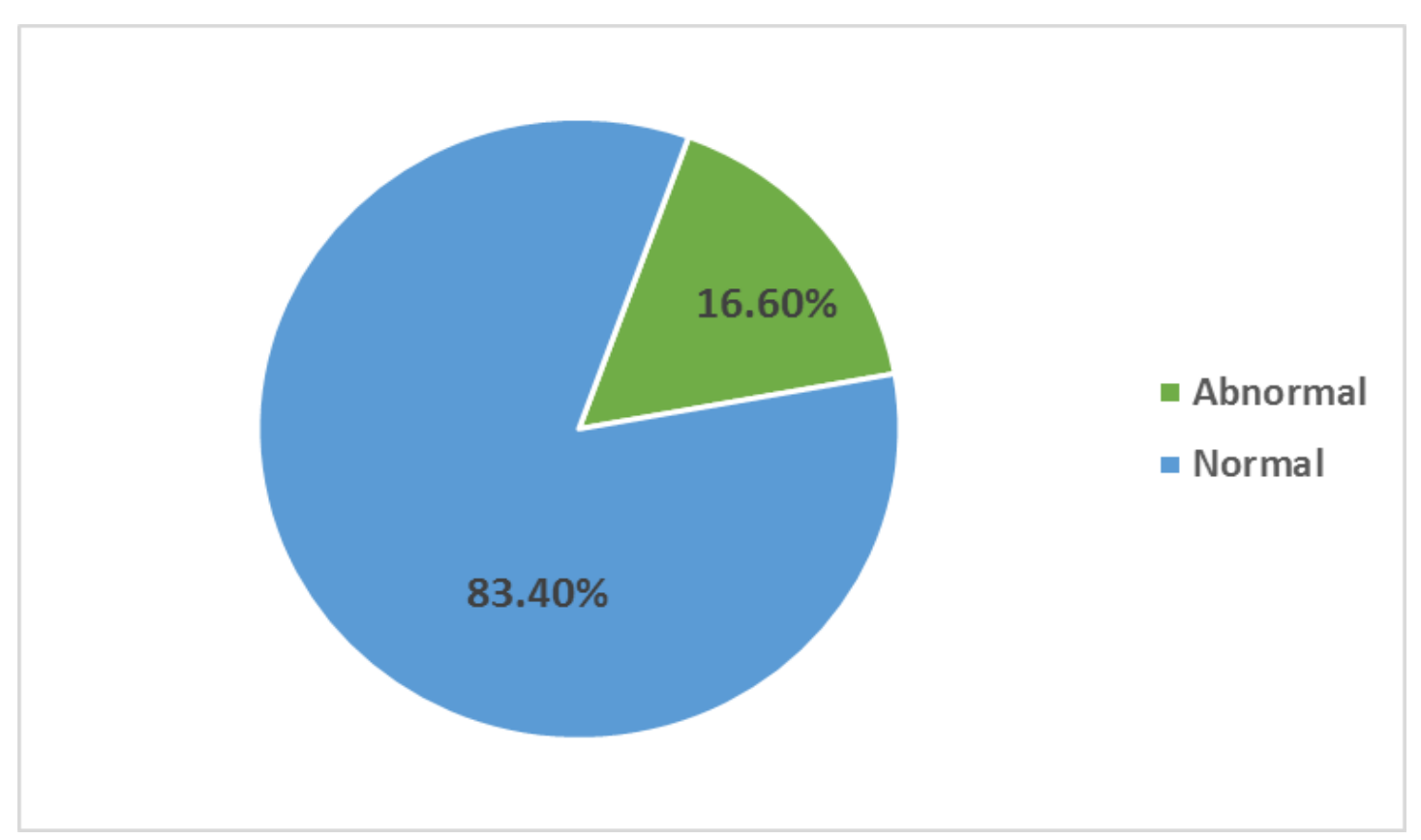

Fig.1: Proportion of abnormal and normal histopathology in abortus. 
The polymerase chain reaction study done for the 72 cases for each of HCMV, Rubella and Herpes simplex virus, shows that about 8 cases $(11.1 \%)$ of the samples were infected with HCMV, and only 2 cases $(2.8 \%)$ are due to rubella infection and one case $(1.4 \%)$ had herpes simplex virus, as shown in Fig 2.

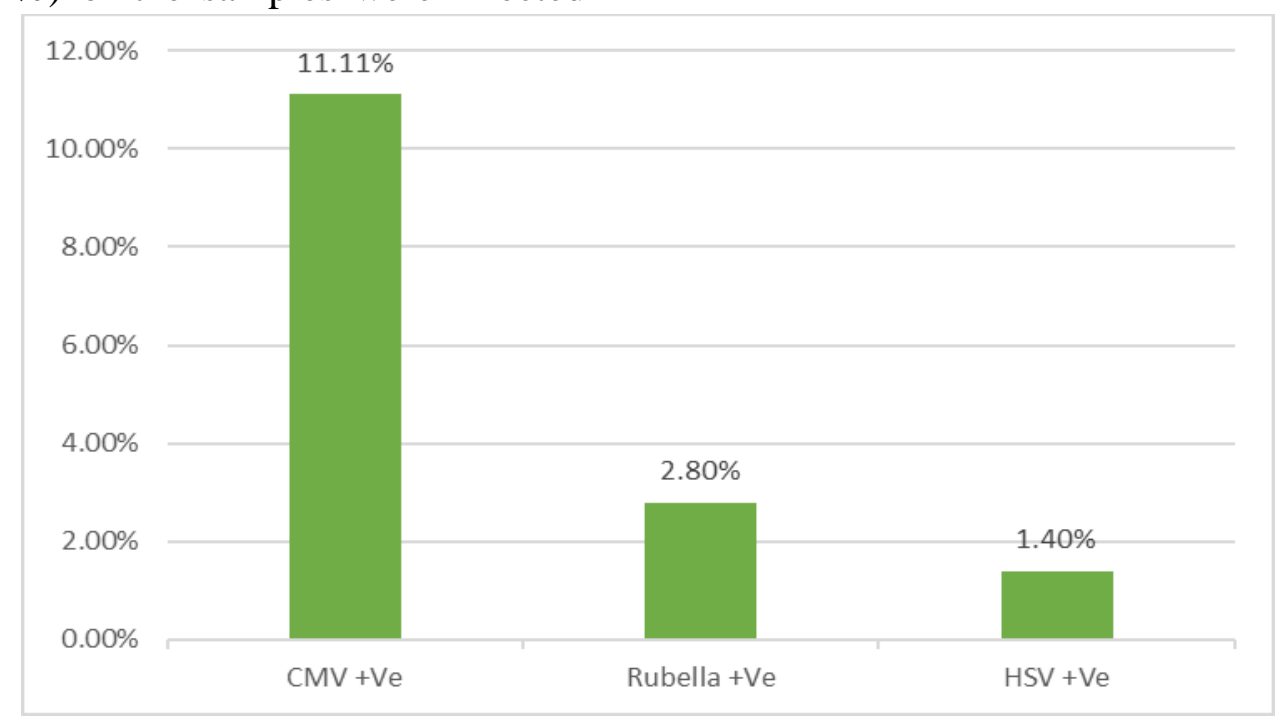

Fig.2: proportions of HCMV, Rubella and HSV infection among study population by $P C R$.

This study found that out of 72 sample of abortion only $9(16.6 \%)$ of them showed histopathological abnormality in form of villitis and only $2(22.2 \%)$

Table 3: Association between PCR outcome and histopathological results of HCMV in the study samples. of these villitis were PCR positive for HCMV, which was statistically nonsignificant as showed in Table 3.

\begin{tabular}{|c|c|c|c|c|c|c|c|}
\hline CMV & \multicolumn{2}{|c|}{$\begin{array}{c}\text { PCR } \\
\text { Positive }\end{array}$} & & $\begin{array}{l}\text { R } \\
\text { tive }\end{array}$ & \multicolumn{2}{|c|}{ Total } & \multirow[t]{2}{*}{ * P-Value } \\
\hline Histopathology & No & $(\%)$ & No & $(\%)$ & No & $(\%)$ & \\
\hline Positive & 2 & $(22.2)$ & 7 & $(77.8)$ & 9 & (100.0) & \\
\hline Negative & 6 & $(9.5)$ & 57 & $(90.5)$ & 63 & $(100.0)$ & 0.257 \\
\hline Total & 8 & (11.1) & 64 & $(88.9)$ & 72 & (100.0) & \\
\hline
\end{tabular}


This study found that out of 72 sample of abortion only 9 (16.6\%) of them showed histopathological abnormality and only $1(11.1 \%)$ of these histopathological abnormalities were PCR positive for Rubella which was statistically significant as showed in Table 4.

Table 4: Association between PCR outcome and histopathological results of Rubella in the study samples.

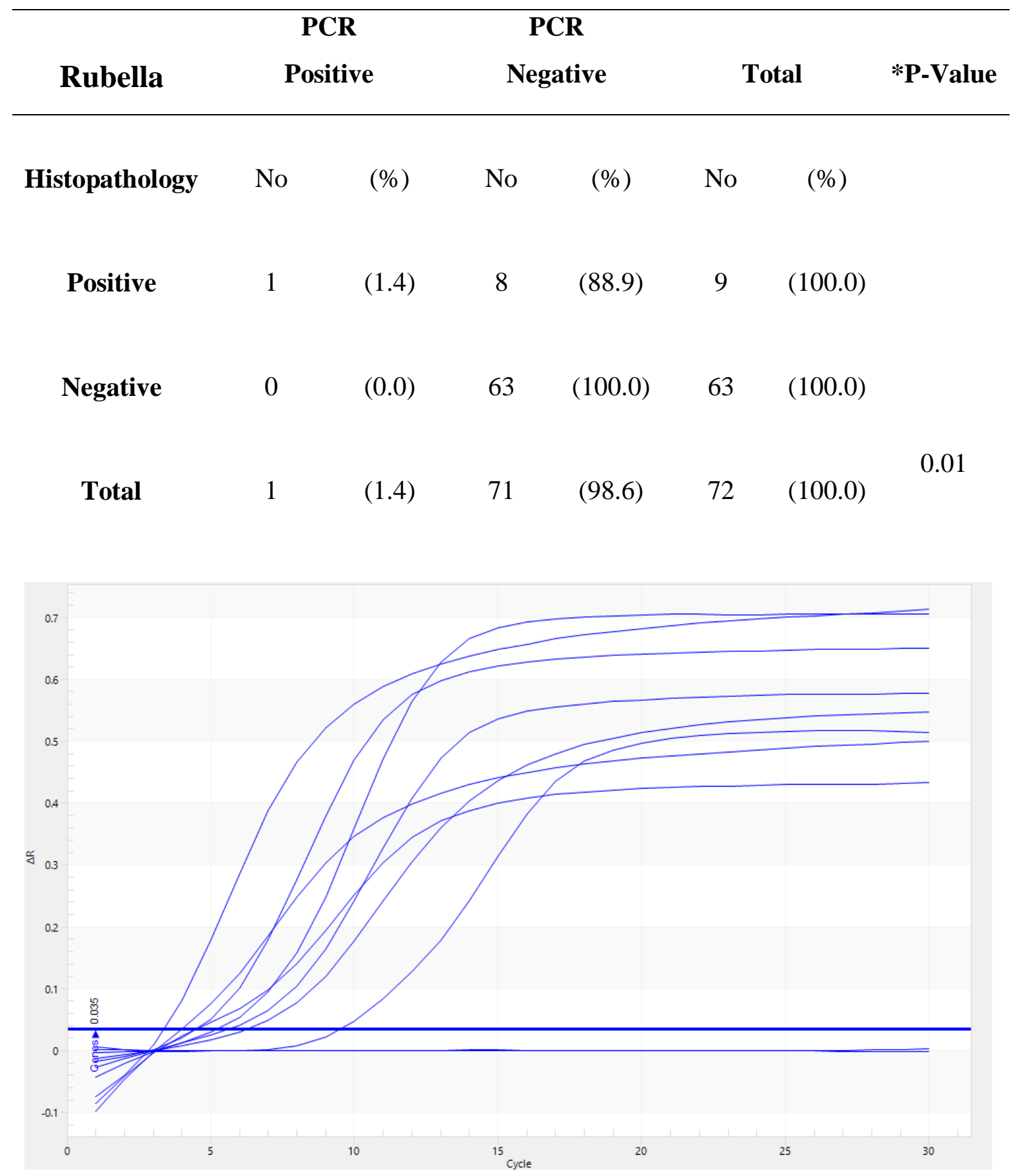

Fig.3: Amplification plot of Polymerase Chain Reaction for HCMV. 


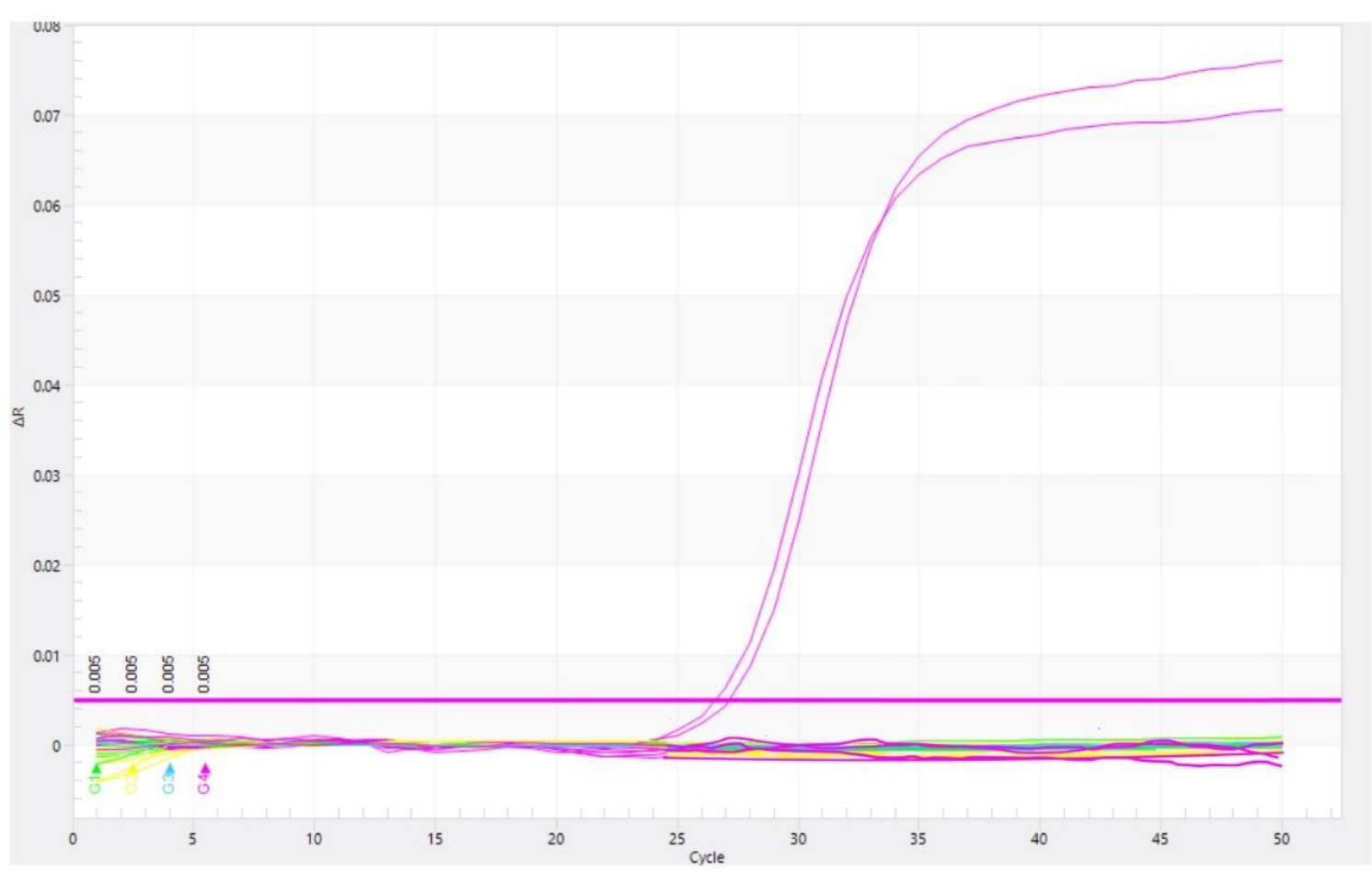

Fig.4: Amplification plot of Polymerase Chain Reaction for Rubella virus.

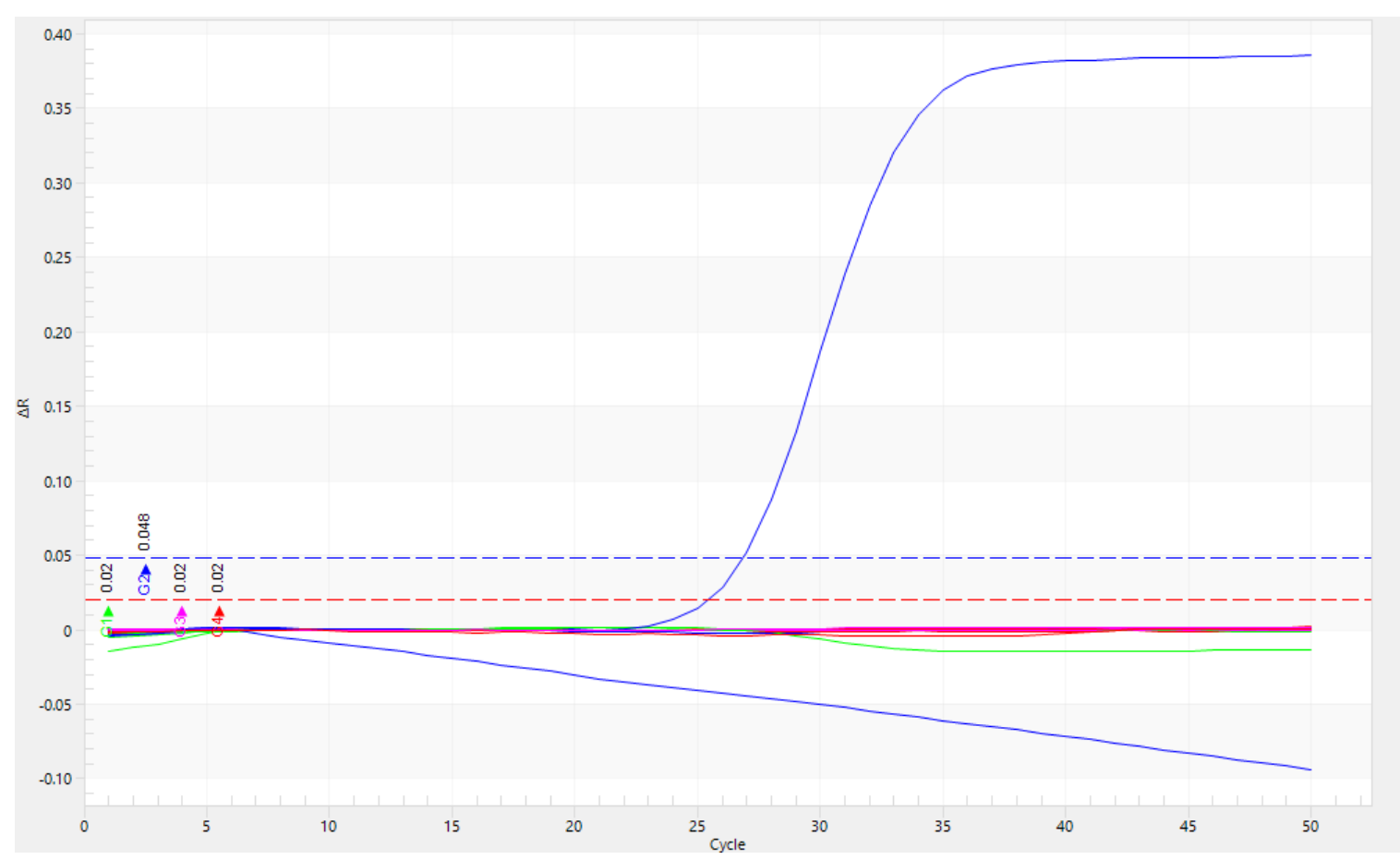

Fig.5: Amplification plot of Polymerase Chain Reaction for Herpes Simplex virus. 


\section{DISCUSSION:}

Abortion is major women's health problems and is the most common type of pregnancy loss, according to the American College of Obstetricians and Gynecologists (ACOG). Studies showed that about $10-20 \%$ of all clinically recognized pregnancies will end in miscarriage, by studying the underline causes and appropriate management will help to reduce miscarriage and provide a healthier babies and healthier mothers (Dugas and Slane, 2020).

Abortion is known as a main cause of maternal mortality, life threatening complications such as hemorrhage, fever, and infection and psychological disorders such as sadness, guilt, and even suicide (Pourreza and Batebi, 2011), Pregnant women are at greatest risk of viral infection, due to that they have changed in immune response (Silasi et al., 2015).

This is first study done in Erbil in order to find viral causes of miscarriage using novel technique in form of polymerase chain reaction with high specificity and sensitivity, the idea was to investigate the viral infection rate among pregnant women with spontaneous abortion. The current study included 72 women with spontaneous miscarriages, among them eight cases $(11.1 \%)$ were found to have HCMV infection. This finding is nearly in consistent with other studies done in our region; like in Bagdad city a study among 108 women with abortion, $15.7 \%$ had CMV specific IgM antibodies (S.Khalf et al., 2012).
And other study done in three provinces Baghdad, Babylon and AlNajaf at teaching hospitals, the study involved 90 case of abortion between first trimester and second trimester the results of real time- PCR (RT-PCR) test for aborted women showed that only $6(6.7 \%)$ cases positive for Cytomegalovirus infection (AlRoubaey, 2018), while in another study done in Turkey found that CMV was positive in two patients out of 134 (1.4\%) (Dinc et al., 2010), and according to another study done in Mansoura University, Egypt, it's found that about $12 \%$ of patient with abortion (el-Sayed Zaki and Goda, 2007).

While in another study done in Tehran found that $5.2 \%$ of women with abortion including repeated abortion are due to HCMV infections (Sotoodeh jahromi et al., 2010), the difference might be related to regional variations and sample size differences.

Data from this study suggest that two $(2.8 \%)$ out of 72 cases were due to rubella and none of them were due to herpes simplex virus, and these findings are nearly in consistence with other studies done in our region ,according to a study done in three provinces Baghdad, Babylon and AlNajaf at teaching hospitals, the study involved 90 aborted women between first trimester and second trimester the results of real time- PCR (RT-PCR) test for aborted women showed that only $12(13.3 \%)$ cases were positive for Rubella virus (Al-Roubaey, 2018).

In a study was carried out on 57 pregnant women with abortion and they were attending Al- Zahra 
Teaching Hospital, in Al-Najaf province, Iraq, the Real Time PCR results showed only 6 out of 57 cases (10.5\%) were positive for Rubella virus (Mahmood et al., 2015). On other hand the results of this study are similar to a study done in Mwanza City, Tanzania, where a total of 268 women with spontaneous abortion were involved in the study for detection of rubella specific IgM antibodies using indirect Enzyme Linked Immunosorbent Assay (ELISA) and the prevalence of acute rubella virus infection was found to be 9/268 (3.7\%) cases (Lulandala et al., 2017).

In this study approximately $1.4 \%$ of abortion samples are due to Herpes Simplex Virus which identified by PCR-technique, which is similar to study done in Al-Batool Teaching Hospital for Maternity and Children in Baqubah city, in which there were $2 \%$ incidence of HSV type1 and 2 in pregnant women (Hussein et al., 2017). On other hand these results are comparable with a study done in Azadi Teaching Hospital, Kirkuk, Iraq, in which incidence of HHSV by ELISA test was 2.6\% (Obaid and Juma, 2017).

While in a study done by Sifakis et al, in Greece in which 102 women with spontaneous abortion was analyzed for the presence of HSV DNA applying the PCR technique, in which only 2 out of 102 cases $(1.9 \%)$ were positive for HSV (Salman, 2017), the difference might be contributed to different technique of detection and sample size difference.

Data from this study suggest that abortion cases are more between age 17-30 years and 31-40 years about
(40.5\%) and (37.5\%) respectively, while; slight decline observed in age group 41-50 years, although high maternal age is a significant risk factor for spontaneous abortion (Andersen et al., 2000), this difference might be due to decrease pregnancy rate after 40 years of age.

In the current study the percentage of abortion among those with low and intermediate economic level were (93.0\%) and most of them about $(72.3 \%)$ were low educational level (non-educated and primary school level), these findings are similar to that reported in a study done in China, revealed that women with high income had a decreased risk of spontaneous abortion when compared with that of women with low income, also a comparison between women in low educational level, women in higher educational level had a lower prevalence of spontaneous abortion (Zheng et al., 2017).

Regarding gestational age at time of abortion, it found that $(88.9 \%)$ were at first trimester, and majority of them having second and third abortion about $(78.2 \%)$ with $(55.6 \%)$ of them were multiparous which is consistent with other studies done in USA and Europe (Cunningham et al., 2013).

Regarding abnormal histopathological finding we found that (22.2\%) of them were due to HCMV by Polymerase Chain Reaction which is nonsignificant, on other hand there are statistically significant association between Polymerase Chain Reaction outcome and histopathological result for Rubella, in which (1.4\%) were positive. This is agreed with study 
done by Chen and Roberts (Chen and Roberts, 2018).

In the current study, there is no significant correlation between the HCMV, Rubella and Herpes Simplex Virus infection in aborted pregnant women with age, education level, occupation, economic level, residence, gestational age, history of abortions and parity, so these cannot be considered as risk factors for infection. The differences between the results of the formerly mentioned studies and the current study could be related to many factors, like the methodology in the current study used molecular technique while other study may use serological methods, sample size, difference of studied population from one area to another, the duration of infection, individual's immune status, demographic and geographical variations, season and etc.

\section{LIMITATION OF THE STUDY:}

many cases of spontaneous abortion are not attending the public hospital

\section{REFERENCES:}

Abdulkadir, A., Gebrehiwot, T.T., 2019. Risk Factors for Rubella Transmission in Kuyu District, Ethiopia, 2018: A Case-Control Study [WWW Document]. Interdisciplinary Perspectives on Infectious Diseases.

Al-Roubaey, D.A.A., 2018. Comparative assessment between immunological and molecular diagnostic methods to rubella virus and cytomegalovirus among Iraqi women with spontaneous abortion. Journal of Pharmaceutical Sciences and Research 10, 640-643.

Al-Talib, A.A., 2016. Clinical presentation and treatment outcome of molar and if they do so, they treated medically rather than surgically and most of them are expelling the product of conception at home.

\section{CONCLUSIONS:}

The present study shows that about $11.1 \%$ of study samples are due to HCMV infection, $2.8 \%$ are due to Rubella infection and only $1.4 \%$ are due to HHSV infection by RT-PCR study, and there were around $16.6 \%$ of the samples shows abnormalities in histopathological analysis with $83.4 \%$ shows no abnormalities.

\section{RECOMMENDATIONS:}

Establishment of a center with high facility for performing PCR study for research purpose. Suggestion for pregnant woman or those planning to become pregnant to be tested for TORCH infections, and vaccinated against Rubella, Cytomegalovirus and Herpes simplex virus to grantee healthy pregnancy outcome.

pregnancy: Ten years' experience at a Tertiary Care Hospital in Dammam, Saudi Arabia. J Family Community Med 23, 161-165.

Alvarado-Esquivel, C., Terrones-Saldivar, M. del C., Hernandez-Tinoco, J., Munoz-Terrones, M.D.E., Gallegos-Gonzalez, R.O., SanchezAnguiano, L.F., Reyes-Robles, M.E., Antuna-Salcido, E.I., 2018. Seroepidemiology of Cytomegalovirus Infection in Pregnant Women in the Central Mexican City of Aguascalientes. J Clin Med Res 10, 337-344.

Andersen, A.-M.N., Wohlfahrt, J., Christens, P., Olsen, J., Melbye, M., 2000. Maternal age and fetal 
loss: population-based register linkage study. BMJ 320, 17081712.

Baker, C.L., Pera, M.F., 2018. Capturing Totipotent Stem Cells. Cell Stem Cell 22, 25-34.

Bialas, K.M., Swamy, G.K., Permar, S.R., 2015. Perinatal cytomegalovirus and varicella zoster virus infections: epidemiology, prevention, and treatment. Clin Perinatol 42, 61-viii.

Bukasa, A., Campbell, H., Brown, K., Bedford, H., Ramsay, M., Amirthalingam, G., Tookey, P., 2018. Rubella infection in pregnancy and congenital rubella in United Kingdom, 2003 to 2016. Euro Surveill 23.

Burton, G.J., Jauniaux, E., 2018. Development of the Human Placenta and Fetal Heart: Synergic or Independent? Front. Physiol.

Carlson, L.M., Vora, N.L., 2017. Prenatal Diagnosis. Obstet Gynecol Clin North Am 44, 245-256.

Carter, A.M., 2018. Recent advances in understanding evolution of the placenta: insights from transcriptomics. F1000Res 7.

Cha, J., Sun, X., Dey, S.K., 2012. Mechanisms of implantation: strategies for successful pregnancy. Nat Med 18, 17541767.

Chaudhry, K., Siccardi, M.A., 2019. Blighted Ovum (Anembryonic Pregnancy), in: StatPearls. StatPearls Publishing, Treasure Island (FL).

Chen, A., Roberts, D.J., 2018. Placental pathologic lesions with a significant recurrence risk - what not to miss! APMIS 126, 589-601.

Cunningham, F.G., Leveno, K.J., Bloom, S.L., Spong, C.Y., Dashe, J.S., Hoffman, B.L., Casey, B.M., Sheffield, J.S., 2013. Abortion, in: Williams Obstetrics. McGraw-Hill Education, New York, NY.
Da Silva, F.T., Gonik, B., McMillan, M., Keech, C., Dellicour, S., Bhange, S., Tila, M., Harper, D.M., Woods, C., Kawai, A.T., Kochhar, S., Munoz, F.M., 2016. Stillbirth: Case definition and guidelines for data collection, analysis, and presentation of maternal immunization safety data. Vaccine 34, 6057-6068.

Dimech, W., Grangeot-Keros, L., VauloupFellous, C., 2016. Standardization of Assays That Detect Anti-Rubella Virus IgG Antibodies. Clinical Microbiology Reviews 29, 163174.

Dinc, B., Bozdayi, G., Biri, A., Kalkanci, A., Dogan, B., Bozkurt, N., Rota, S., 2010. Molecular detection of cytomegalovirus, herpes simplex virus 2 , human papillomavirus 16 18 in Turkish pregnants. Brazilian Journal of Infectious Diseases 14, 569-574.

Donnelly, L., Campling, G., 2019. Functions of the placenta. Anaesthesia \& Intensive Care Medicine 20, 392-396.

Downs, K.M., 2018. Extragonadal primordial germ cells or placental progenitor cells? Reproductive BioMedicine Online 36, 6-11.

Dugas, C., Slane, V.H., 2020. Miscarriage, in: StatPearls. StatPearls Publishing, Treasure Island (FL).

Ebrahimi-Rad, M., Shakeri, T.S., Shirvani, F., Shahrokhi, K., Shahrokhi, N., 2017. Prevalence of congenital cytomegalovirus infection in symptomatic newborns under 3 weeks in Tehran, Iran. BMC Infect Dis 17.

el-Sayed Zaki, M., Goda, H., 2007. Relevance of parvovirus B19, herpes simplex virus 2, and cytomegalovirus virologic markers in maternal serum for diagnosis of unexplained recurrent abortions. Arch. Pathol. Lab. Med. 131, 956960. 
Erkurt, M., 2018. Emergence of form in embryogenesis. Journal of The Royal Society Interface 15, 20180454.

Giakoumelou, S., Wheelhouse, N., Cuschieri, K., Entrican, G., Howie, S.E.M., Horne, A.W., 2016. The role of infection in miscarriage. Hum Reprod Update 22, 116-133.

Homer, H.A., 2019. Modern management of recurrent miscarriage. Australian and New Zealand Journal of Obstetrics and Gynaecology 59, 36-44.

Hussein, A.A., Salman, S.T., Khashman, B.M., 2017. FREQUENCY OF HUMAN CYTOMEGALOVIRUS AND HUMAN HERPESVIRUS-1 ANTIGENS IN PRODUCT OF CONCEPTUS TISSUES OF PREGNANT WOMEN WITH SPONTANEOUS ABORTION. IRAQI JOURNAL OF MEDICAL SCIENCES 15, 94-102.

Iwasawa, T., Takahashi, K., Goto, M., Anzai, M., Shirasawa, H., Sato, W., Kumazawa, Y., Terada, Y., 2019. Human frozen-thawed blastocyst morphokinetics observed using time-lapse cinematography reflects the number of trophectoderm cells. PLOS ONE 14, e0210992.

Kaushik, A., Verma, S., Kumar, P., 2018. Congenital rubella syndrome: $A$ brief review of public health perspectives. Indian Journal of Public Health 62, 52.

Lambert, N., Strebel, P., Orenstein, W., Icenogle, J., Poland, G.A., 2015. Rubella. Lancet 385, 2297-2307.

LeGoff, J., Péré, H., Bélec, L., 2014. Diagnosis of genital herpes simplex virus infection in the clinical laboratory. Virol. J. 11, 83.

Licci, S., Licci, S., 2017. Intrauterine fetal death due to congenital cytomegalovirus infection. Brazilian Journal of Infectious Diseases 21, 567-568.
Lindholm, K., O’Keefe, M., 2018. Placental Cytomegalovirus Infection. Archives of Pathology \& Laboratory Medicine.

Loutradi, K.E., Tarlatzis, B.C., Goulis, D.G., Zepiridis, L., Pagou, T., Chatziioannou, E., Grimbizis, G.F., Papadimas, I., Bontis, I., 2006. The effects of sperm quality on embryo development after intracytoplasmic sperm injection. J Assist Reprod Genet 23, 69-74.

Lulandala, L., Mirambo, M.M., Matovelo, D., Gumodoka, B., Mshana, S.E., 2017. Acute Rubella Virus Infection among Women with Spontaneous Abortion in Mwanza City, Tanzania. J Clin Diagn Res 11, QC25-QC27.

M, S., Y, M., 2014. [The life cycle of Rubella Virus]. Uirusu 64, 137146.

Mahmood, T.A., Sultan, B.A., Mohammed, S.N., Hucheimi, S.N.A.-, 2015. Serological and Molecular Diagnosis of Rubella virus and Cytomegalovirus in aborted Patients in Al-Najaf province. kufa Journal for Nursing sciences 5, 99-105.

Mandal, M., Chaudhuri, A., Banerjee, D., Kanrar, P., Hazra, S.K., 2017. Impact of management protocols of intrauterine fetal death on perceived stress: A comparative study. Journal of the Scientific Society 44, 121.

Marqui, A.B.T. de, Marqui, A.B.T. de, 2018.

Chromosomal abnormalities in recurrent miscarriages by conventional karyotyping analysis. Revista Brasileira de Saúde Materno Infantil 18, 265-276.

Marsico, C., Kimberlin, D.W., 2017. Congenital Cytomegalovirus infection: advances and challenges in diagnosis, prevention and treatment. Ital J Pediatr 43. 
Mhandire, D., Rowland-Jones, S., Mhandire, K., Kaba, M., Dandara, C., 2019. Epidemiology of Cytomegalovirus among pregnant women in Africa. The Journal of Infection in Developing Countries 13, 865-876.

Mouri, Mi., Rupp, T.J., 2019. Threatened Abortion, in: StatPearls. StatPearls Publishing, Treasure Island (FL).

Nguyen, T.V., Pham, V.H., Abe, K., 2015. Pathogenesis of Congenital Rubella Virus Infection in Human Fetuses: Viral Infection in the Ciliary Body Could Play an Important Role in Cataractogenesis. EBioMedicine 2, 59-63.

Obaid, H.M., Juma, S.A., 2017. TORCH Screening Test in Pregnant Women of Kirkuk City. AlMustansiriyah Journal of Science 27, 17-25.

Opstelten, R., Slot, M.C., Lardy, N.M., Lankester, A.C., Mulder, A., Claas, F.H.J., van Rood, J.J., Amsen, D., 2019. Determining the extent of maternal-foetal chimerism in cord blood. Scientific Reports 9, 1-10.

Pourreza, A., Batebi, A., 2011. Psychological Consequences of Abortion among the Post Abortion Care Seeking Women in Tehran. Iran J Psychiatry 6, 31-36.

Putri, N.D., Wiyatno, A., Dhenni, R., Sriyani, I.Y., Dewantari, A.K., Handryastuti, S., Iskandar, A.T.P., Rahma, M.M., Jumiyanti, N., Aprilia, Y.Y., Prayitno, A., Karyanti, M.R., Satari, H.I., Hadinegoro, S.R., Myint, K.S.A., Safari, D., 2019. Birth prevalence and characteristics of congenital cytomegalovirus infection in an urban birth cohort, Jakarta, Indonesia. International Journal of Infectious Diseases 86, 31-39.

Ranjbaran, H., Abediankenari, S., Khalilian, A., Rahmani, Z., Momeninezhad Amiri, M., Hosseini Khah, Z., 2018.
Differentiation of Wharton's Jelly Derived Mesenchymal Stem Cells into Insulin Producing Cells. Int J Hematol Oncol Stem Cell Res 12, 220-229.

Razonable, R.R., Inoue, N., Pinninti, S.G., Boppana, S.B., Lazzarotto, T., Gabrielli, L., Simonazzi, G., Pellett, P.E., Schmid, D.S., 2020. Clinical Diagnostic Testing for Human Cytomegalovirus Infections. J Infect Dis 221, S74-S85.

Rouse, C.E., Eckert, L.O., Babarinsa, I., Fay, E., Gupta, M., Harrison, M.S., Kawai, A.T., Kharbanda, E.O., Kucuku, M., Meller, L., Mallett Moore, T., Subelj, M., Kochhar, S., Tavares-Da-Silva, F., 2017. Spontaneous abortion and ectopic pregnancy: Case definition \& guidelines for data collection, analysis, and presentation of maternal immunization safety data. Vaccine 35, 6563-6574.

Rovito, R., Claas, F.H.J., Haasnoot, G.W., Roelen, D.L., Kroes, A.C.M., Eikmans, M., Vossen, A.C.T.M., 2018. Congenital Cytomegalovirus Infection: Maternal-Child HLA-C, HLA-E, and HLA-G Affect Clinical Outcome. Front. Immunol. 8.

Salman, J., 2017. PCR Detection of Herpes Simplex-2 Virus in Human Placenta in Patients with Spontaneous Abortion. International Journal of ChemTech Research 10, 545-551.

Sapra, K.J., Joseph, K.S., Galea, S., Bates, L.M., Louis, G.M.B., Ananth, C.V., 2017. Signs and Symptoms of Early Pregnancy Loss. Reprod Sci 24, 502-513.

Schleiss, M.R., 2016. Preventing Congenital Cytomegalovirus Infection: Protection to a "T." Trends Microbiol 24, 170-172.

Sheng, G., Foley, A.C., 2012. Diversification and conservation of the extraembryonic tissues in 
mediating nutrient uptake during amniote development. Ann N Y Acad Sci 1271, 97-103.

Shi, T.-L., Huang, L.-J., Xiong, Y.-Q., Zhong, Y.-Y., Yang, J.-J., Fu, T., Lei, X.-F., Chen, Q., 2018. The risk of herpes simplex virus and human cytomegalovirus infection during pregnancy upon adverse pregnancy outcomes: A metaanalysis. J. Clin. Virol. 104, 48-55.

S.Khalf, M., W.Ahmad, D., A.Ibraheem, K., 2012. The Seroprevalence of IgM Among Iraqi Aborted Women Infected with Human Cytomegalovirus. Iraqi Postgraduate Medical Journal 11.

Soler, A., Morales, C., Mademont-Soler, I., Margarit, E., Borrell, A., Borobio, V., Muñoz, M., Sánchez, A., 2017. Overview of Chromosome Abnormalities in First Trimester Miscarriages: A Series of 1,011 Consecutive Chorionic Villi Sample Karyotypes. CGR 152, 81-89.

Sotoodeh jahromi, A., Makiani, M., Farjam, M., Madani, A., Malihe, A., Eftekhaari, T., Sima, H., 2010. Cytomegalovirus Immunity in Pregnancy in South of Iran. American Journal of Infectious Diseases 6.

Stein, K.R., Gardner, T.J., Hernandez, R.E., Kraus, T.A., Duty, J.A., Ubarretxena-Belandia, I., Moran, T.M., Tortorella, D., 2019. CD46 facilitates entry and dissemination of human cytomegalovirus. Nature Communications 10, 1-13.

Sumankuuro, J., Crockett, J., Wang, S., 2017. Maternal health care initiatives: Causes of morbidities and mortalities in two rural districts of Upper West Region, Ghana. PLoS One 12.

Syrkasheva, A.G., Dolgushina, N.V., Romanov, A.Y., Burmenskaya, O.V., Makarova, N.P., Ibragimova, E.O., Kalinina, E.A., Sukhikh, G.T.,
2017. Cell and genetic predictors of human blastocyst hatching success in assisted reproduction. Zygote 25, 631-636.

Theofanakis, C., Drakakis, P., Besharat, A., Loutradis, D., 2017. Human Chorionic Gonadotropin: The Pregnancy Hormone and More. Int J Mol Sci 18.

Verbruggen, S.W., Oyen, M.L., Phillips, A.T.M., Nowlan, N.C., 2017. Function and failure of the fetal membrane: Modelling the mechanics of the chorion and amnion. PLoS One 12.

Woyessa, A.B., Ali, M.S., Korkpor, T.K., Tuopileyi, R., Kohar, H.T., Dogba, J., Baller, A., Monday, J., Abdullahi, S., Nagbe, T., Mulbah, G., Kromah, M., Sesay, J., Yealue, K., Nyenswah, T., Gebrekidan, M.Z., 2019. Rubella transmission and the risk of congenital rubella syndrome in Liberia: a need to introduce rubella-containing vaccine in the routine immunization program. BMC Infectious Diseases 19, 813.

Zakharova, E.E., Zaletova, V.V., Krivokharchenko, A.S., 2014. Biopsy of Human Morula-Stage Embryos: Outcome of 215 IVF/ICSI Cycles with PGS. PLOS ONE 9, e106433.

Zalei, B., Pourmand, D., Desfolimanesh, Z., Ghaderi, O., 2017. Cytomegalovirus seroepidemiology in pregnant women presented to the Central Laboratory of Kermanshah, Iran in 2014. Annals of Tropical Medicine and Public Health 10, 826.

Zanga, J., Mbanzulu, M.K., Kabasele, A.-F., Ngatu, N.R., Wumba, D.R., 2017. Rubella Seroprevalence and realtime PCR detection of RUBV among Congolese pregnant women. BMC Infectious Diseases $17,250$. 
Zheng, D., Li, C., Wu, T., Tang, K., 2017. Factors associated with spontaneous abortion: a crosssectional study of Chinese populations. Reproductive Health 14, 33.

Zhou, H., Liu, Y., Liu, L., Zhang, M., Chen, X., Qi, Y., 2016. Maternal pre- pregnancy risk factors for miscarriage from a prevention perspective: a cohort study in China. European Journal of Obstetrics and Gynecology and Reproductive Biology 206, 57-63. 